\title{
Effects of Monitoring and Evaluation Practices on The Performance of Health Projects Under Centre for Health Solutions (CHS) in Nyeri County, Kenya
}

\author{
JAMES TITUS GACHANJA KINYUA*, Dr. NAOMI NDUTA NJOROGE (Ph.D.) ** \\ * MA (Monitoring and Evaluation) Student, Department of Social and Development Studies, School of Social Science, Mount Kenya \\ University, Kenya \\ ${ }^{* * *}$ Lecturer, Department of Social and Development Studies, School of Social Science, Mount Kenya University, Kenya:
}

DOI: 10.29322/IJSRP.11.09.2021.p11757

http://dx.doi.org/10.29322/IJSRP.11.09.2021.p11757

\begin{abstract}
In the 21st century, health issues are considered among significant social challenges around the world. Non-Governmental Organisations in Nyeri County, Kenya, and globally such as the Center for Health Solutions, among other stakeholders, have established a couple of health projects focused on addressing health-related issues. Nevertheless, regardless of these efforts, the general picture of health project performance in Nyeri County has remained inadequate as well as health issues have continued to persist. Yet, insufficient studies have been conducted concerning this phenomenon. Information regarding health project performance is scarce, and efforts to compare the data are limited. To improve the performance of health projects, which will reduce rising health issues, the use of monitoring and evaluation practices is inevitable. This study aimed to identify the effects of M\&E practices and the performance of health projects under the Centre for Health Solutions in Nyeri County. The following specific objectives guided the study; to assess the effects of planning for M\&E on health projects performance, to determine the significance of capacity building of the $M \& E$ team on the performance of health projects and, to examine the effects of M\&E data quality maintenance on the performance of health projects under the Centre for Health Solutions. This study was anchored by the program theory and result evaluation theory. The current study embraced a descriptive survey to study the effects of M\&E practices on health project performance under CHS in Nyeri County. The study targeted a total of 71 participants working under CHS health projects. Due to the small size of the target population, all the participants from the different project sections were censured as the study respondents. These included one CHS Nyeri project coordinator, six health project managers, two M\&E officers, 19 health record officers, 18 clinicians, and 25 social workers. This study used a close-ended questionnaire to collect quantitative and an interview guide to collect qualitative data, and secondary data was collected by carrying out document analysis. To guarantee the validity of the data collection instruments, professionals were referred to, and their additions were added in the concluding version of the data collection instruments. Reliability was assessed through Cronbach Alpha, and it was established that a normal coefficient of 0.84 was accomplished, implying that the data collection instruments were reliable. The quantitative data was analyzed using SPSS to run inferential
\end{abstract}

statistics and descriptive statistics, and the collected qualitative data were analyzed using thematic analysis. Quantitative data were presented in tables and graphs, and chi-square was used to test the study hypothesis. The study used regression and correlation analysis to identify the link between the study variables. The study findings established a significant positive relationship between the $\mathrm{M} \& \mathrm{E}$ practices, planning for $\mathrm{M} \& \mathrm{E}$, capacity building of the $M \& E$ team and $M \& E$ data quality maintenance (independent variables) and performance of health projects (dependent variables) under CHS in Nyeri County, Kenya. The study concluded that an organisation determines if the projects it undertakes would achieve the desired goals based on the M\&E practices it conducts. Consequently, the study also concluded that an organisation that devotes itself to guaranteeing effective M\&E practices enhances the performance of its projects. From the study findings, Organisations should provide resources for $M \& E$ that are adequate and timely. Consequently, the study recommends $5 \%$ to $10 \%$ of the organisation budget should be allocated to the M\&E department since they have a significant effect on the performance of health projects. The study also recommends that NGOs should frequently organise regular training on Monitoring and Evaluation; this would support increasing the knowledge in M\&E. Finally, it is essential for an organisation to regularly train the $\mathrm{M} \& \mathrm{E}$ team on effective monitoring and evaluation data collection tools and methods. The findings may also be a source of information to other researchers interested in carrying out further research.

Key Words: Monitoring and Evaluation practice, Performance, M\&E Data Quality Maintenance, Strengthening M\&E team, Planning for $M \& E$

\section{INTRODUCTION}

\section{Background of the Study}

The need for Monitoring and Evaluation (M\&E) practices was initiated in 1973 when the World Bank's Independent Evaluation Group (IEG) supported M\&E usage. Since then, World Bank has continued to support government efforts in developing countries through strengthening their M\&E systems and practices (Mackay, 2007). According to a study by Nyakundi, (2014), the use of M\&E 
practices has grown to be very important globally since they are used in economic, social, political, and environmental projects. As a result, organizations have emphasized the need to plan for $\mathrm{M} \& \mathrm{E}$, capacity building of the $\mathrm{M} \& \mathrm{E}$ team, and maintaining the $\mathrm{M} \& \mathrm{E}$ data quality.

Monitoring and Evaluation practices such as maintaining M\&E data quality, capacity building of the M\&E team, and planning for M\&E continue to be used extensively on health projects because they form crucial elements in managing projects (Kirori \& Karanja, 2019). Muindi, (2018) observes that the M\&E practices serve as a core part of the project's cycle and adopting practices such as regularly training the M\&E staff, employing skilled M\&E personnel, and using technology to collect M\&E data, they facilitate the increment of project productivity, project management, and project implementation.

M\&E practices make it possible for all involved stakeholders to assess the progress of the development projects, to know whether they are on track to achieving the anticipated benefits. NGOs that make use of $M \& E$ practices can account for all the resources utilized and providing helpful feedback to the donors (Gwagoya, 2017), Efficient utilization of $M \& E$ data results and proper allocation of $M \& E$ resources and $M \& E$ budget ensures the achievement of development projects' goals and objectives (Maalim, 2017). A project is considered as accomplished and thriving after the accomplishment of the project objectives.

Using M\&E practices effectively on health projects guarantees the success of projects and observable project performance that meets all key stakeholders' project objectives and expectations. Furthermore, effective use of M\&E practice guarantees health projects perform by producing desirable deliverables of quality and within the set time and budget (Micah, 2017; Shapiro, 2011; Njuguna, 2016). UNDP (2016) sums up that without ample use of M\&E practices, knowing project direction and establishing project success and performance would be a challenge.

Using M\&E practices provides valuable information used during the planning, decision making, budgeting, and the making of policies that have led to development effectiveness (Ochieng, Chepkuto, Tubey, \& Kuto, 2017). In addition, the use of M\&E practices that are systematic in health projects brings about an increase in efficiency during assessing project performance. Hence, the need of using reliable M\&E data sources, regularly training the $\mathrm{M} \& \mathrm{E}$ team, using appropriate $\mathrm{M} \& \mathrm{E}$ data collection tools and methods, stakeholder participation, and M\&E personnel with skills and experience to boost the opportunities for a health project to be successful and increase project performance.

A report by World Bank, (2017), utilizing previous M\&E results during planning for $\mathrm{M} \& \mathrm{E}$ in health projects, offers health project managers, donors, and decision-makers a better way to learn from the past health projects, this leads to improving planning, services delivery, allocation of resources, and demonstrating the achieved results as a way of accountability to the critical health project shareholders. Furthermore, using high M\&E data quality in health projects leads to the sharing of knowledge and organizational learning; this enables NGOs to learn and share their experiences from their health project and know what to do to future health projects to get full benefits.

Many nations, mainly the developed countries, have adopted more effective M\&E practices enabling them to pursue results-oriented health initiatives (Gwagoya, 2017). First world nations, like
Canada, the United States of America (USA), Russia, China, and Sri Lanka, use Monitoring and Evaluation practices that are well structured, planned, and flexible. These countries have steady decentralization of resources that trickle down to the local governments, enabling monitoring and evaluation practices. Institutionalizing M\&E practices in health projects has created a podium that allows proper $\mathrm{M} \& \mathrm{E}$ budget and $\mathrm{M} \& \mathrm{E}$ resource allocation during planning for $\mathrm{M} \& \mathrm{E}$, leading to the careful monitoring and evaluation of projects. According to Khan, (2018), these practices allow these countries to track the progress of the health projects efficiently and effectively, leaving no chance of having incomplete health projects and low health project performance.

Most countries in Europe and the United States of America, according to INTRAC (2017), have successfully implemented $\mathrm{M} \& \mathrm{E}$ practices in their health projects. However, many other regions such as Central Asia and Africa are behind in successfully incorporating $\mathrm{M} \& \mathrm{E}$ practices. These countries have incidences of poor data quality, failure to involve stakeholders or utilize previous $M \& E$ results during planning for $M \& E$, some do not regularly train their M\&E staff, and some don't allocate enough resources or budget towards M\&E (PMI, 2013). The USA government has laid in place the guidelines by highlighting the importance of $\mathrm{M} \& \mathrm{E}$ practices in development projects critically. Toscano (2019) carried out a review in the USA to emphasize that the guidelines enabled accuracy when accessing project progress and project performance.

The Government of Canada has documented that health project achievement is because of proper use of M\&E practices. High M\&E data quality has made it possible to follow up and trail projects progress against project goals (Lahey, 2009). The Canadian government has invested in M\&E practices to maintain accountability and achieve results in the health sector. Similarly, as observed by Guzmán, Irarrázaval, \& Ríos, (2020), Chile is another developed country that, for a long time, has had regular and efficient M\&E practices in the health sector. Chile has observed success in the health projects because of using M\&E practices such as capacity building of the M\&E team, availability of quality data for M\&E, allocation of sufficient financial resources for $\mathrm{M} \& \mathrm{E}$, and proper planning for $\mathrm{M} \& \mathrm{E}$.

Monitoring and Evaluations is an evolving field in Africa as compared to developed nations around the globe. Nevertheless, the use of M\&E practices has seen remarkable progress in SubSaharan Africa (Princeton University, 2016); South Africa is among the few African countries with notable improvement. Significant growth of M\&E practices usage in South Africa is observed through the continued success of the health sector after the apartheid rule under all the governments since Nelson Mandela. In addition, in 2009, during President Zuma's first month in office, he introduced the Performance Monitoring and Evaluation Ministry to increase public service deliverance after citizens' outcry regarding the slow government rate of delivering public services (Hubert \& Mulyungi, 2018).

The Ministry ensured that for the success of health projects and other development projects, M\&E practices such as having skillful M\&E staff, providing training to the $M \& E$ team, maintaining quality data for $\mathrm{M} \& \mathrm{E}$, stakeholder involvement during planning for $M \& E$ is paramount. Other Sub-Saharan Africa countries such as Kenya, Zimbabwe, and Ghana have shown outstanding efforts 
to progress M\&E practices use in health projects as well as further development projects. National Development Planning commission (NDPC) was a commission formed by the Ghana government to integrate the M\&E principle in Ghana development projects. Kiura, (2017) did a study in Ghana, showing that Ghana purposely insisted usage of M\&E practices promote good governance, cost-effectiveness, strengthening institutional capacity, credibility, and accountability of private and public institutions.

Findings by (NDPC 2006) show that NDPC, during the introduction of the Ghana Poverty Reduction Strategy 1 (GPRS) in 2003, also implemented M\&E practices to make it easier for tracking the progress of projects, their implementation, and effectiveness. Ghana's government has continued to use M\&E practices to assist the increased resource distribution and designing of future development projects (Hubert \& Mulyungi, 2018). With all the significant progress, Ghana still faces several challenges when implementing health projects and development projects, as observed by CLEAR (2012). They include poor quality of data, limited budgetary and resource allocation for $\mathrm{M} \& \mathrm{E}$ $\mathrm{f}$, weak capacity, operational problems, lack of trained personnel, low stakeholders' involvement, poor planning, and the failure to strengthen and harmonize existing M\&E practices

Back in 2000, Kenya tried the first shot to use Monitoring and Evaluation to monitor Interim Poverty Reduction Strategy Paper (IPRSP), but this had its weaknesses (CLEAR, 2012). During the same period, development partners such as NGOs, private entities, and Civil Society Organizations (CSOs) practiced M\&E not harmonized, nor did they share their M\&E reports with the government or among themselves. These development partners faced challenges such as the shortage of skilled and experienced M\&E staff, lack of M\&E financial resources, and the use of lowquality data that brought about the failure to adopt $\mathrm{M} \& \mathrm{E}$ practices in their projects (Anunda, 2016).

Similarly, findings from a study done by Njenga (2018) acknowledged that NGOs faced the unavailability of skilled M\&E staff, poor $M \& E$ reporting, and poor $M \& E$ data quality, greatly influencing $\mathrm{M} \& \mathrm{E}$ findings. To solve these issues, the Kenya government in 2003, with Vision 2030 and the State for Planning Ministry, Monitoring \& Evaluation Directorate (MED), was developed to manage and harmonize M\&E activities countrywide. In 2003 MED came up with the National Integrated Monitoring and Evaluation System (NIMES) to help in M\&E of development projects and fast delivery of services.

Another reason why NIMES was developed; was to assist the Kenyan Government in measuring the effectiveness and efficiency of development projects and to offer a transparent process by which the NGOs, private entities and Civil Society Organizations can share their M\&E reports with the government and the donor community (Samburu County Government, 2017). According to a study done by Ndung'u (2018) on elements that impact the execution of M\&E practices in Construction Projects under the Nyeri County Government. The research study highlighted that, despite all determinations to build up the use of M\&E practices in development projects, numerous accomplishments had been attained by using NIMES. However, implementation of M\&E still faces challenges such as weak M\&E culture, inadequate capital, infrastructure, and resources, lack of reliable and timely data, lack of adequate performance tracking capability, lack of well-trained staff, and lack of local M\&E training institutes.

The Kenyan Government has partnered with NGOs to help in delivering some of the goals in the health policy, MDGs, and Vision 2030. In Kenya, the number and size of NGOs have continued to grow over the years and funds from donors and the Kenya Government, but this has led to increased concerns regarding trying to identify their achievements. The troubles are associated with unsuccessful efforts to institute the use of $M \& E$ practices in NGOs. By capacity building of the M\&E practices and enhancing the existing ones, NGOs will observe an improvement of health project success and project performance. Although most of these NGOs use monitoring and evaluation practices, they do so to impress the donors. As highlighted by Khan (2017), the use of the M\&E methods helps NGOs provide an account of the activities that take place, the direct outputs, and provide helpful information indicating how health projects achieved the set objective and how the health projects performed.

According to KPMG, (2019), the continued health hazards and challenges faced around the developing countries can be controlled and reduced if the concerned parties would utilize $M \& E$ practices in health projects then report what is working and what is not working to enable the enhancement of strategies to counter the fails in the health projects Findings from a study done by Njenga, (2018) regarding effects of M\&E practices on maternal health projects under NGOs highlighted M\&E practices are vital by helping NGOs in tracking health project progress and measuring health project effects and performance. Monitoring and evaluation practices guarantee that health project outcomes can be regulated to provide a framework essential during accountability and assist when making informed decisions during future health projects.

In Nyeri County, there has been a notable increase in NGOs concerned about providing health development aid. They include Centre for Health Solutions - Kenya, Kiini Sustainable Initiative, Mercy Cops, Population Services Kenya, Amref Health Africa, Eagle Neema Health Rights Advocacy Forum, Christian Health Association of Kenya, Family Health International, Kenya Red Cross, JhPiego and United States Agency for International Development (USAID).

The growth in NGOs has led to increased concerns regarding health projects' success and performance. However, with all the effort towards addressing the health issue in Nyeri, health remains to contribute substantially to the mortality rates, which ends up inconveniencing many families while draining the health systems in Nyeri County (Nyeri County, 2019).

Several stakeholders have undeniably raised worries concerning the success and performance of NGO health projects, mainly due to the absence of effective working policies on M\&E practices (KPMG, 2019). A couple of health projects supported by these NGOs have been achieved while a few are on planning, and others are being implemented. However, health projects under NGOs are limited, and health challenges are reducing at a slow rate, making it essential to identify how M\&E practices affect health project performance under NGOs in Nyeri. Against this background, this research study will look into the effects of $M \& E$ practices on performance of health projects under the Centre for Health Solutions in Nyeri County, Kenya. 


\section{Problem Statement}

The Kenyan Government has partnered with NGOs such as the Centre for Health Solutions (CHS) to help in delivering some of the goals in the health policy, MDGs, and Vision 2030. CHS works in corporation with donors, local communities, Kenyan Government, and other stakeholders to supplement sustainable health services. In addition, CHS supports the implementation of enhanced health services in Kenya through sustainable health projects by working closely with the Ministry of Health.

In Nyeri, the number and size of NGOs have continued to grow over the years and funds from donors and the Kenya Government. Yet, the county continues to record increasing numbers of patients with non-communicable diseases and those infected with tuberculosis, increasing concerns regarding trying to identify NGO achievements. In addition, the failure to recognize the health project achievements under NGOs has led to increased interest by the donors who have continued to fund the NGOs year in year out. As a result of this, donors insist on M\&E practices usage in health projects to increase accountability, projects success, and improve performance in the projects. However, studies done by Dobi, (2019) and (Kihuha, 2018) indicate that majority of the NGOs have weak M\&E practices or lack M\&E practices and end up recording weak project performance, and this is per quality scope, resource utilization and timeline measurements.

An extensive review of studies indicates that with all the advantages achieved by embracing the usage of monitoring and evaluation practices in projects, very little attention or no attention has been given to the M\&E practices' effects on health projects performance under NGOs. Similarly, most of the previous studies carried out in Nyeri County on M\&E practices focused on various contexts other than the performance of health projects such as the performance of construction projects, youth projects, agricultural projects, and water projects. From this health project, managers and NGO management lack information on the effects of M\&E practices on the health project performance, leading them to give little priority to $\mathrm{M} \& \mathrm{E}$ practices deteriorating health project performance.

However, despite the efforts made to adjust and streamline using monitoring and evaluation practices in NGOs, the performance of CHS health projects has not met the expectations of the funder organizations or has remained below the donors' expectations. Therefore, to address this existing gap, the current study will look into the effects of M\&E practices on the performance of health projects under the Centre for Health Solutions in Nyeri County. With a focus on how, planning for M\&E, capacity building of the $M \& E$ team, and $M \& E$ data quality maintenance affects health project performance under CHS in Nyeri County.

\section{Objectives of the Study}

The study was guided by the following objectives.

1. To assess the effects of Planning for M\&E on the performance of health projects under Centre for Health Solutions in Nyeri County

2. To determine the effects of Capacity Building of the M\&E team on health projects performance under Centre for Health Solutions in Nyeri County

3. To examine the effects of M\&E Data Quality Maintenance on the performance of health projects under Centre for Health Solutions in Nyeri County.

\section{Research Hypothesis}

The stated hypothesis guided the study.

1. Ho: Planning for $M \& E$ has no significant effect on health projects performance under Centre for Health Solutions in Nyeri County

$\mathrm{H} 1$; Planning for M\&E has a significant effect on health projects performance under Centre for Health Solutions in Nyeri County

2. Ho: Capacity building of the $M \& E$ team has no significant effect on health projects performance under Centre for Health Solutions in Nyeri County $\mathrm{H} 1$; Capacity building of the M\&E team has a significant effect on health projects performance under Centre for Health Solutions in Nyeri County

3. Ho: M\&E data quality maintenance has no significant effect on health projects performance under Centre for Health Solutions in Nyeri County

$\mathrm{H} 1$; $\mathrm{M} \& \mathrm{E}$ data quality maintenance has a significant effect on health projects performance under Centre for Health Solutions in Nyeri County

\section{LITERATURE REVIEW}

\section{Theoretical Review}

\section{Effects of Planning for Monitoring and Evaluation on the} Performance of Health Projects

At the beginning of any project, planning for $\mathrm{M} \& \mathrm{E}$ is essential since it provides a comprehensive guideline for what the project aims to achieve. Planning for M\&E should factor in stakeholder participation, $M \& E$ results utilization, budget allocation for $M \& E$. and resource allocation for M\&E. Effectively carried out planning for $\mathrm{M} \& \mathrm{E}$ leads to high health project performance.

Lack of stakeholder involvement during planning for $\mathrm{M} \& \mathrm{E}$ commonly affects health project performance. This statement is supported by a study done by Izurieta, et al., (2019) to identify the $M \& E$ indicators for management effectiveness in Australia. The participation of stakeholders during planning for M\&E ensures that the strategies accurately reflect their needs and priorities. Khan, (2017) did a study in Pakistan and highlighted that the involvement of stakeholders during preparation for $\mathrm{M} \& \mathrm{E}$ on health projects promotes the feeling of project ownership during the entire project. To add weight to this, a study by Stephen, (2015) review the effects of $\mathrm{M} \& \mathrm{E}$ practices of NGOs implementing HIV/AIDS Projects in Uganda; this motivates them to sponsor the project leading to its success and performance.

A report in Africa from IFAD, (2016), shows that using M\&E results during the making of decisions affects appropriate corrections done on the project activities. The observation is backed by another report in Africa by INTRAC (2015) that using $M \& E$ results provides a strong foundation from which the right judgments are made regarding ways to ensure project objectives and record-high performance in projects. The $M \& E$ results from previous health projects are beneficial, as they assist throughout planning for M\&E and health project management. Kiura, (2017), in his study to examine the effects of M\&E Strategies on the implementation of NG-CDF Projects in Kirinyaga. The researcher identified that $M \& E$ results utilization contributes to project 
success and high project performance. The usage of M\&E results from previous health projects during planning for $\mathrm{M} \& \mathrm{E}$ guarantees the provision of helpful information that is utilized to ensure the achievement of project performance.

Findings of research carried out by Akello and Moronge, (2019) to inspect the effects of $M \& E$ practices on government-funded agricultural projects performance in Marsabit concluded from their analysis using regression coefficients that participation of stakeholders during planning for $\mathrm{M} \& \mathrm{E}$ is a critical factor since this contributes highly to the agricultural project's performance in semi-arid and arid areas that the government funds. Another study carried out by Mushori, (2015) in Nakuru established that participation of stakeholders during planning for M\&E has an essential effect on project success and contributes to high project performance. Stakeholders' involvement encourages maximum project participation and commitment by the stakeholders leading to high project performance.

As indicated by a report by IFAD, (2016) majority of the developing countries have a challenge in the implementation of health projects because of the failure to allocate enough M\&E resources during planning for $\mathrm{M} \& \mathrm{E}$, adding weight to this statement, a study was done by Abraham, (2018) recommended that, during planning for $\mathrm{M} \& \mathrm{E}, \mathrm{M} \& \mathrm{E}$ budget allocation should be done correctly to prevent wrongful allocation of the funds that would lead to a challenge in implementing health projects. In support of this observation, the findings by Gwagoya, (2017) highlighted that the lack of sufficient funds affects the implementation of projects, further hindering the performance of projects.

A similar line of thinking, a study was done by Nduta, (2018) on M\&E strategies, highlights that for efficient M\&E activities, budget distribution for M\&E of any project must be satisfactory. According to Mwangio and Moronge, (2019), budget allocation for $M \& E$ should be defined clearly so that the $M \& E$ activities can independently utilize its resources. In addition to this Maina, (2016) made recommendations that the M\&E budget should not consume a lot of the allocated health project resources ending up disrupting other health project activities. But, on the other hand, it should not be too little hence influencing health projects' credibility, accuracy, and performance.

During planning for $\mathrm{M} \& \mathrm{E}$, the distribution of resources meant for M\&E should be carried out controllably within the organizations to aid in the implementation of the project (Ongondo, 2017). In her study, Nduta (2018) found that some organizations have experienced low project performance; this happens when no allocation of resources is meant for the $\mathrm{M} \& \mathrm{E}$, irrespective of organizations having appropriate funds planned for projects. Findings by Sanganyi, (2016) about the execution of M\&E practices in infrastructure projects noted that proper resource allocation dedicated to $\mathrm{M} \& \mathrm{E}$ activities leads towards low project performance. The researcher also recommended that during planning for $M \& E$, the distribution of resources must be estimated accurately to prevent running out of resources before completing project implementation. It can be noted that the absence of adequate resources for $\mathrm{M} \& \mathrm{E}$ has a negative effect on health project performance.

A study was done by Njeri and Omwenga, (2019) on the influence of $M \& E$ practices on sustainable projects identified that it is crucial to create a project activity schedule during planning for
M\&E, which will be used during project implementation to compare the actual timeline of activities and the planned activities schedule and determine if the project being implemented is within the course of out of sequence. Stephen (2015) recommended that during planning for $\mathrm{M} \& \mathrm{E}$, the cautious scheduling of activities from one step to another facilitates the achievement of the set objectives. Scheduling activities make it easy to keep the plan on track, leading to the success of health projects and high project performance (Mensah, 2017). In addition, scheduling activities make it easier for the health project staff to monitor and control the project execution since this enables them to track their operations, learn and improve their services as per the project activities schedule to ensure high project performance.

\section{Effects of Capacity Building of the Monitoring and Evaluation Team on the Performance of Health Projects}

A study in India by Bennett, Singh, S. Ozawa, Tran, and Kang (2018) confirms that the team accountable for monitoring and evaluating is usually a crucial power that drives a project. This observation is supported by Edge and Hoffman (2016) in a study to identify the impact of recruiting M\&E personnel in Australia, Canada, the UK, and the USA. The researchers' findings found that project managers need to acknowledge the significance of capacity building of the M\&E team to achieve success and high performance in health projects.

A study by Alex (2016) on the assessment of M\&E systems performance in South Sudan identified that capacity building of the M\&E team in health projects enhances the health project's performance and success. Likewise, (Idoro 2019) in his study, the influence of $M \& E$ practices in the Nigerian Construction Companies confirms that suitable M\&E practices directly contribute to project success and high performance hence making the need to have a capacity to build M\&E staff critical to accomplishing health project objectives. The findings of a study done by Mugo (2017) regarding M\&E, Ethics \& Sustainability of Agricultural Food Crop Projects in Nyeri show that a project with a well capacity build M\&E team contributes towards better planning for $\mathrm{M} \& \mathrm{E}$, and project control becomes more flexible and satisfactory.

Monitoring and Evaluation staff who frequently handle data in a project, as observed by Marsden, Caffrey, and McCaffery (2017), must be regularly trained on skills that involve $M \& E$ data collection, reporting of data, interpretation of data, and analysis of data. Findings of research completed by Demissie, (2015) on assessment on project monitoring and evaluation system in Ethiopia identified that lacking skilled M\&E staff required in interpreting, managing, and using $\mathrm{M} \& \mathrm{E}$ data contributes towards a generation of low-quality M\&E data, which contributes to poor health projects implementation hence low health projects performance. Regular training ensures that the M\&E team is up to date with all new M\&E developments, therefore, building upon their M\&E data handling skills.

A study done by (Maphunye, 2018) on human capacity challenges in the implementation of M\&E practices in South Africa noted that undertaking $M \& E$ should invest heavily in $M \& E$ staff training and development, which will be a way to capacity build the M\&E team. In the study carried by Ika, Diallo, and Thuillier (2018) on Project Management in International project Development, the researchers noted that $\mathrm{M} \& \mathrm{E}$ staff training, and capacity building 
entail a comprehensive variety of activities such as internship, coaching, formal training, mentorship, and in-service training. Projects having M\&E staff located in the field, Muiga, (2015) recommends that they should have regular and intensive capacity building and on-site training; this directly increases the skills of M\&E staff located in the field. When health projects have a strong M\&E team that is fully dedicated to $\mathrm{M} \& \mathrm{E}$, full-time trained, and possess the right skills, this will increase the quality of the $M \& E$ team and subsequently lead to health project success and high health project performance.

According to Wanja (2017), health projects cannot efficiently operate without a skilled M\&E team who can execute $M \& E$ effectively and engage in the $M \& E$ requires skills and capacity on the M\&E team. This finding is further backed by Mibey, (2016), who did a review on elements influencing the application of M\&E practices in the Kazi Kwa Kijana project in Kakamega, found out that skills and competency should be considered as one of the critical components of project success and high project performance. As indicated by (INTRAC, 2017), having dedicated and enough M\&E staff is essential, but having an M\&E team that possesses the right skills for a health project is highly vital to the success and performance of health projects.

Personnel in the health project management field, such as evaluators, M\&E officers, health project managers, and health project staff, need to undergo frequent $\mathrm{M} \& \mathrm{E}$ and project management specialized training. The findings of a research review by Magaku, (2010) on the effects of M\&E on Women Enterprise Funded Projects performance found that women project performance was insufficient due to $M \& E$ staff, project managers, and project staff who lacked specialized training in M\&E and project management. Providing training and development offers the M\&E staff and health project managers technical skills, increasing job satisfaction, which reflects high project performance. When health projects are handled by M\&E staff, health project managers, and health projects staff with sufficient training, the likelihood of health project success is high.

The M\&E staff experience is the overall time the M\&E staff has been engaged in M\&E (Mathis \& Jackson, 2015). A highly experienced and well-trained M\&E team ensures smooth health projects implementation with minimal errors, leading to less money and time (Mthethwa \& Jili, 2016). When the M\&E staff of vast experience handles a health project, there is a high likelihood of project performance. Findings of a review by Mulandi, (2013) on elements influencing M\&E systems performance of NGOs in Nairobi identified that, when M\&E is practiced by staff who lack experience, this tends to be expensive and time-consuming. Hence, the project results could be unrelated, unrealistic, and irrelevant, which influences the project's success and performance. Therefore, it is evident that when a health project has a well experienced $\mathrm{M} \& \mathrm{E}$ team project, success and high project performance will be achieved.

When an organization has large projects, they need to use a sizeable M\&E team. Likewise, when they have a small project in size, the size of the team they require remains just a small one (Hubert \& Mulyungi, 2018). The findings of Kaburu, (2015) on elements influencing the M\&E systems performance in NGOs in Nairobi established that for an M\&E team to be efficient in delivering its project responsibilities, the staff number should match the volume of work being carried out to avoid overworking some staff leading to poor performance, this shows that M\&E staff number is directly related to the work required. Hence, this leads to enhanced success and the performance of health projects.

\section{Effects of Monitoring and Evaluation Data Quality Maintenance on the Performance of Health Projects}

Maintaining quality $\mathrm{M} \& \mathrm{E}$ data enhances health project progress, success, and performance; low-quality data will directly affect the performance of health projects. As identified by other studies: Demissie, (2015); Gwagoya, (2017); Ika, Diallo, and Thuillier, (2018); Kihuha, (2018); Kirori and Karanja, (2019); Muchelule, (2018); Ngumbau, (2015); Njeri, (2018); Njuguna,(2016); Stephen, (2015); Wanja, (2017), the authors describe M\&E data as an essential factor during health projects planning and implementation and also as a management instrument, because when the M\&E data is of high quality, health projects administrators can: identify the significant constraints and problems faced during the implementation of the health project, the successes achieved during implementation, make adjustments in the health project activities, carry out appropriate M\&E budget allocation, proper planning for upcoming health projects and to be able to provide accurate information to government agencies, stakeholder and donors about the health project accountability, performance and success.

A study carried out in Australia by Patric \& Kingsley, (2019) on barriers and enablers to $M \& E$ in health programs recommended that $M \& E$ data collection tools ought to have the precision to collect and record what they are designed to collect and record hence ensuring the achievement of high-quality M\&E data. Findings by Velasco, (2018) on critical principles of data quality in India highlights that when planning to carry out data collection for $\mathrm{M} \& \mathrm{E}$, assessing data collection tools and methods is vital concerning the following data quality attributes, data reliability, the accuracy of data, data precision, data completeness, and timeliness of data. According to Worthington, (2016), a researcher in South Africa, in a study on ways to improve data quality, recommended that having data collection tools that generate accurate monitoring and evaluation data reduces errors such as sampling errors, interviewer bias, transcription errors and recording errors, and this leads towards the generation of $\mathrm{M} \& \mathrm{E}$ data that is of high-quality.

Similarly, Kissi, et al., (2019), in the study on the effects of M\&E practices on construction projects in Ghana, highlights that data collection tool gives the same accurate, complete, and reliable data collection tool and precision after repeated measurements. Doing this, as observed by Hubert \& Mulyungi, (2018) in their study on the effects of $M \& E$ practices on construction projects in Rwanda, leads to the obtaining of high-quality M\&E data, which significantly contributes to better health project decision making that leads to health project success and high health projects performance. Therefore, guided by this observation, maintenance of $M \& E$ data quality shall lead to successful projects and high performance of health projects.

M\&E data is usually used to guide health project operations and policies (Gebremedhin, Getachew, and Amha, 2018). To add weight to this, findings from a study by Nasambu, (2016) on factors influencing the implementation of M\&E in NGOs based in Uganda recommended that maintaining high $M \& E$ data quality creates an environment where sound decisions are made. The 
researcher further suggests that this can be achieved by; having a system that accommodates regular data quality checks, having a mechanism that has a provision of feedback, and data auditing. In addition, an organization ought to maintain data collection tools and data collection protocols according to international standards to achieve high-quality M\&E data (Ika, Diallo, \& Thuillier, 2018). By doing so, the results obtained can be used in other future health projects and can also be used as a comparison across countries and the given country.

To achieve high data quality, there is a need to implement advanced technology on the data collection tools; this will contribute to the generation of accurate, reliable, complete, precise, and timelessness (Defontaine, 2018). In an organization that emulates the use of technology in all $\mathrm{M} \& \mathrm{E}$ data related functionality, issues that erode $M \& E$ data quality will not be familiar. Therefore, the health project planning and implementation will not be affected, leading to success in health projects and the achievement of high project performance; this observation was recommended by Waithera \& Wanyoike (2015) to identify the effect of M\&E on agribusiness projects in Nakuru. The entire M\&E staff in an organization should be taught both data dissemination and $\mathrm{M} \& \mathrm{E}$ data collection for them to be able to perform data analysis and data assessment efficiently and effectively (Njeri \& Omwenga, 2019). Furthermore, the organization should ensure the availability of data quality assessment and analysis tools and M\&E data quality improvement groups equipped with the necessary skills to assess and carry out M\&E data analysis (Jennifer, 2015). The generation of highquality data will be of importance to project success and high project performance. It is, therefore, evident that when M\&E staff are trained on the interpretation of data, data collection methods and tools, reporting of data, and analysis of data, this contributes to achieving high-quality $M \& E$ data that provides relevant information required during health projects decision making that will affect the performance of health project.

The source of M\&E data is highly crucial to the credibility of the reported results. Therefore, $\mathrm{M} \& \mathrm{E}$ staff needs to integrate $\mathrm{M} \& \mathrm{E}$ data from multiple best sources to validate and verify the findings. Mulandi (2013) noted that data validation and verification ensure $M \& E$ data from the various data sources is complete, reliable, and accurate. A study carried out by Ngumbau, (2015) to identify the role played by data quality assessment in the performance of HIV prevention projects in Nyeri County found out that, M\&E team are required to utilize best data sources such as private sector members; partner organizations such as CBOs and NGOs; experts from the area of study; members of the society who have the experience in the field of study; researchers; government agencies; processed info and raw data from previous studies to achieve highquality M\&E data. Magondu, (2016) supports this statement through a review of elements influencing the implementation of $M \& E$ in HIV research projects, obtaining data from the best M\&E data sources guarantees high-quality $M \& E$ data that is validated and verified, which subsequently contributes to the success of health projects and high health project performance.

The frequent $M \& E$ data collection results in more data points; the more the data points, the more the relevant stakeholders understand the dynamics of the intervention, such as project, policy, or program. Many M\&E data points lead to high-quality M\&E data buildup essential to project success and project performance (Mibey, 2016). Similarly, findings from a study done by Mwangi and Moronge, (2019), the effects of M\&E practices on World Bank-funded project performance in Nairobi, recommended that carrying out frequent data collection enhances $\mathrm{M} \& \mathrm{E}$ reporting in projects and directly complements the data required for project performance. Routine data collection aids in maintaining high data quality. The frequently collected M\&E data shall be used during the middle and final evaluation. The relevant stakeholders will use it to assess the project's progress against estimated results and performance level.

\section{Gaps Identified from the Literature}

Regardless of the growing interest in the effects of M\&E practices on project performance, inadequate research has been done on $M \& E$ practice implications on health projects performance under NGOs in Nyeri County. These are some of the studies prepared based on M\&E practices and its effects to projects performance: Akello and Moronge, (2019); Anunda, (2016), Dobi, (2019); Gwagoya, (2017); Kihuha, (2018); Kirori and Karanja, (2019); Muchelule, (2018); Muiga, (2015); Mushori, (2015); Ndung'u, (2018); Njenga, (2018); Njeri, (2018); Njuguna, (2016); Ochieng, Chepkuto, Tubey, and Kuto, (2017); Ramothamo, (2015); Sanganyi, (2016); Shihemi, (2016); Stephen, (2015); Wambua, (2019): Wanja, (2017). These studies identified and revealed some of the best M\&E practices to apply, leading to an increase in project performance.

Research was done by Stephen, (2015) to show the effects of implementing M\&E practices on NGOs' HIV and AIDS projects in Nakaseke and Luwero, Uganda. The study used a descriptive research method. The main goal was to determine the effectiveness of M\&E practices on Non-Governmental Organizations implementing HIV and AIDS projects. The researcher found out that a couple of $M \& E$ practices, for instance, capacity building of the $\mathrm{M} \& \mathrm{E}$ team by training, lack of enough funds to carry out M\&E activities, the NGOs did not fully utilize little involvement of stakeholders during planning for M\&E. The study recommended the need to improve $M \& E$ practices for project implementation increasing project success of a project and its performance. To build upon these findings, the current study will examine the effects of selected $M \& E$ practices on health project performance under $\mathrm{CHS}$, which is an NGO in Nyeri County.

Findings from a review done by Wambua, (2019), to know the effects of $M \& E$ practices on performance of education projects funded by Makueni County., the research established to what level usage of the baseline survey, M\&E team training, stakeholder's participation and planning for M\&E effects education projects performance funded by Makueni County. The researcher identified that usage of baseline surveys, training of the M\&E team, and participation of stakeholders significantly affected county-funded education project performance, unlike M\&E planning, which had little effects. The review recommended to attain high performance of projects, all stakeholders should be involved in planning, and more funds should be allocated towards the $M \& E$ team training to capacity build the M\&E team. To add to this existing knowledge and build on these findings, the current study will investigate how $M \& E$ data quality maintenance, capacity building of the $M \& E$ team, planning for $M \& E$ effects health project performance under CHSs in Nyeri County. 
In an investigation by Njeri and Omwenga, (2019), effects of M\&E practices on sustainable projects under the National Aids Control Council, the study aimed to identify the effects of the $\mathrm{M} \& \mathrm{E}$ communication, $\mathrm{M} \& \mathrm{E}$ organization factors, M\&E human capacity, partnership in $M \& E$ on a sustainable project. The authors determined that organization factors for $\mathrm{M} \& \mathrm{E}, \mathrm{M} \& \mathrm{E}$ communication ensured sustainability on projects under the National Aids Control Council. Still, the human capacity for M\&E was not a well-utilized M\&E practice. The authors recommended the importance of the human capacity for M\&E, which hampered the sustainability of projects under the National Aids Control Council. This current study will investigate whether the same observation will be generated from the effects of planning for $M \& E, M \& E$ data quality maintenance, Capacity Building of the M\&E team, and on the precise health projects performance under CHS, an NGO in Nyeri County.

Findings from research carried out by Mugo, (2017) on the effects of M\&E Practices, Ethics and Sustainability in agricultural food projects in Nyeri, the study use, the use of research and surveillance, M\&E data demand, M\&E capacity building and planning for $M \& E$ as objectives to guide the study. The study used the mixed-method research design approach through correlation survey and descriptive research design using questionnaires, observation, and interviews to collect data. The study focused on agricultural food projects while the current research will study the effects of M\&E practices on health project performance.

Findings from a study by Maalim, (2017) regarding the effects of M\&E practices on project performance in Mombasa, concentrating on budgetary allocation, use of baseline surveys, the involvement of stakeholders, and capacity building as the independent research variables. The study used a descriptive research design to collect data and identified that capacity building, use of baseline surveys, the involvement of stakeholders, and budgetary allocation are essential ingredients in the success of a project and what leads to the high performance of projects. To add to this existing knowledge and build on these findings, this study will investigate how $M \& E$ data quality maintenance, planning for $M \& E$ and, Capacity Building of the M\&E team affects health project performance under CHS, an NGO in Nyeri County

A study was undertaken by Ndung'u, (2018) effects of M\&E practices in Nyeri County Government construction projects adopting a mixed research design approach. The study concluded that all the objectives, budgetary allocation stakeholder involvement, policy framework, and top management support affected the execution of Nyeri county government construction projects greatly. The researcher made recommendations to increase $M \& E$ training to capacity build the $M \& E$ team. The current study shall investigate if similar observation will be observed on health projects performance under NGOs. The study shall also increase the knowledge body of knowledge that exists by identifying the effects of M\&E practices on the performance of health projects under CHS, an NGO in Nyeri County.

From a review carried out by Njeri, (2018) to examine the effects of project management practices in health projects under public hospitals in Nyeri, using the theory of constraints and system theory as an anchor, the study made use of descriptive crosssectional survey design and sampled the sample size using stratified random sampling and simple random sampling. Semi- structured questionnaires were used to collect the data. The review established that project planning, project funding, and government policies were significant during health project implementation, and project funding was identified as a critical variable. The researcher recommended that increasing the involvement of stakeholders promotes the feeling of project ownership during the entire project and promotes the maximum project participation by the stakeholders. The current study shall add knowledge to the already existing through the identification of the effects of M\&E practices on performance of health projects specifically under CHS, an NGO in Nyeri County using the following objectives: capacity building of the $\mathrm{M} \& \mathrm{E}$ team, planning for $\mathrm{M} \& \mathrm{E}$ and $\mathrm{M} \& \mathrm{E}$ data quality maintenance.

From reviews done from past studies and the literature review, this confirms that lots of work have been done to have effective M\&E practices. Nevertheless, not much research has been done on $M \& E$ practices and there effects on the performance of health projects more so under any NGOs in Nyeri County. The review of the literature did not find a study that combined the three variables capacity building of the $M \& E$ team, planning for $M \& E$, and $M \& E$ data quality maintenance. The study shall pursue to fill those gaps by concentrating on how; capacity building of the M\&E team, planning for $\mathrm{M} \& \mathrm{E}$, and $\mathrm{M} \& \mathrm{E}$ data quality maintenance affects the performance of health projects under CHS in Nyeri County.

\section{RESEARCH METHODOLOGY}

\section{Research Design}

The current study embraced a descriptive survey to study the case of health project performance under CHS in Nyeri and collect, analyze, and present data relating to planning for $M \& E$, capacity building of the $M \& E$ team, and $M \& E$ data quality maintenance. A descriptive survey was proposed in this study because it was ultimate in bringing into consideration the numerous standpoints, viewpoints, and perceptions positions using both quantitative and qualitative approaches. Objectively it allowed the researcher to simplify the results beyond a specific setting, situation, or event, hence minimizing any bias and maximizing the reliability of the information to be collected. Furthermore, using quantitative and qualitative approaches allowed the researcher to compare the evidence by cross-validating, confirming, and substantiating the findings.

This design involved collecting quantitative data for carrying out inferential statistics and descriptive analysis to determine the connection between dependent and independent variables. Bhat, (2019) noted that the quantitative approach aims to describe the current situations and show the relationships between the given variables; in other conditions, a quantitative approach is also used by researchers to describe the causal relationship among the various variables of interest. The qualitative approach was used to explore and describe the phenomenon under study. This approach collected in-depth information using a structured interview guide from the key informants of the study. An in-depth analysis of the health projects under CHS uncovered the causes of high performance or low performance of health projects. 


\section{Target Population}

The study's target population was 71 participants involving; one CHS Nyeri project coordinator, six health project managers, two monitoring and evaluation officers, 19 health record officers, 18 clinicians, and 25 social workers involved in the health projects in the health facilities supported by CHS. The study was based on the health projects under the Center for Health Services and all the respondents associated with those health projects. Therefore, the target censured population remained as 71 respondents.

\section{Sampling Procedures}

The study was based on the health projects under the Center for Health Services (CHS) and the respondents associated with those health projects. Due to the small size of the target population, all the participants from the different project se1ctions were censured as the study respondents. They included one CHS Nyeri project coordinator, six health project managers, two M\&E officers, 19 health record officers, 18 clinicians, and 25 social workers. Census allowed the study of the entire population, reducing sampling error, which provided an accurate measure of the target population (Lammer \& Badia, 2013).

\section{Testing for Validity and Reliability}

Data collection instruments were tested for validity and reliability, this was done to improve their accuracy, meaningfulness and remove any vagueness on the items on the data collection instruments. Content validity was the most appropriate in measuring data collection instrument validity in this study. To establish the research instrument reliability, the researcher used internal consistency to measure the reliability of the newly created data collection instrument. Cronbach's Alpha Coefficient was used to compute and estimate the reliability of the newly created data collection instrument.

\section{Data Analysis Techniques and Procedures}

Qualitative and quantitative collected data were analyzed, qualitative data obtained from the interview guide was analyzed using thematic analysis techniques per the study objectives, and data was presented in narrative quotations within the study. The collected quantitative data from the closed-ended questionnaires were entered into a computer after being coded for analysis and computation using the Statistical Package for Social Sciences (SPSS version 20).

The SPSS was used to run both inferential and descriptive statistic. Descriptive was presented through percentage, frequencies, mean, and standard deviation to show, describe, and summarize the data in a meaningful manner. Additionally, quantitative data were presented in the form of graphs, tables, charts. At the same time, inferential statistics involved regression analysis and correlation analysis in establishing the link involving study independent and dependent variables.

Multiple regression was applied to determine connection among variables in relation to strength and direction. It was also used to measure the interrelationship between the three independent variables and their effects on health projects performance initiated by CHS.

The multiple regression model algebraic expression consists of a constant term coefficient and error term as shown below.
$Y=\beta_{0}+\beta_{1} X_{1}+\beta_{2} X_{2}+\beta_{3} X_{3}+\varepsilon$

Where:

$\mathrm{Y}=$ Performance of health projects under CHS

$\mathrm{X}_{1}=$ Planning for $\mathrm{M} \& \mathrm{E}$

$\mathrm{X}_{2}=$ Capacity Building of the M\&E staff

$\mathrm{X}_{3}=\mathrm{M} \& \mathrm{E}$ Data Quality Maintenance

$\varepsilon=$ error term, for purposes of calculation, $\varepsilon$ is presumed to be 0 .

$\beta_{0=}$ represents a constant term

$\beta_{1,2,3}=$ represents coefficients

For this study, the hypothesis was tested through a chi-square X2 at a confidence level of $5 \%$ based on the analysis output from SPSS. Chi-square was used because the quantitative data collected was non-parametric. Chi-square was calculated using the formula shown below.

$$
\begin{aligned}
& X^{2}=\sum_{i=0}^{n} \frac{(\mathrm{Oi}-\mathrm{Ei})^{2}}{\mathrm{Ei}} \\
& \mathrm{O}=\text { Observed } \\
& \mathrm{E}=\text { Expected }
\end{aligned}
$$

\section{RESEARCH FINDINGS}

\section{Reliability Results}

To measure the reliability of the data collection instruments, the researcher used Cronbach alpha. It was established that a normal coefficient of 0.866 was accomplished, while all the variables attained a coefficient above 0.80 . This was like Nasambu, (2016) findings on reliability testing, where the study used the reliability index of 0.857 , which was enough to generate the reliability under this study. This implied that the data collection instrument for the current study was reliable since the recommended reliable coefficient should be above 0.7 as recommended by (Statistics, 2018).

\section{Response Rate}

From the study, the used censured population was 71 respondents, all from CHS in Nyeri County. To get answers for the research questions, closed-ended questionnaires were administered to 65 respondents. In addition, interviews were conducted using a structured interview schedule with seven key informants; however, only 56 closed-ended questionnaires were returned. This represented a response rate of $86.15 \%$, which is over the recommended response rate of 50\% (Defontaine, 2018) required to validate the consistency of data collection instruments as needed for analysis. Subsequently, this response rate was around the range of other scholars. Maalim, (2017) had a response rate of $68.86 \%$ and Muchelule, (2018) used an average response rate of $86.5 \%$ in their studies on M\&E practices.

All key informants gave the researcher a chance to administer the structured interview schedule.

\section{Demographic Data of Respondents}

This study aimed to identify the demographic data of the respondents in terms of gender, age, level of education, respondent's position in the organization and work experience as the results indicated below. 


\section{Gender Information of the Respondents}

On the questionnaires, the respondents were required to capture their gender to allow the participants to be analyzed and discussed based on gender. Study findings illustrate that, most of the respondents who returned the questionnaires were females, who were 36 , representing $64.29 \%$, while male respondents were 20 , representing $35.71 \%$. However, irrespective of this, the study findings indicate that there is gender equality in the employment of the staff in CHS. This shows that the opinions were gendersensitive and can be used as an illustrative of both male and female opinions regarding the effect of $M \& E$ practices on the performance of health projects under CHS.

However, from the study findings, it was observed that there was an absence of gender equality in health record officers and social workers. Out of the 18 health record officers, 12 were females while 6 were males, and out of the 20 social workers, 16 were females while 4 were males. This shows gender imbalance among the health record officers and social workers in the health projects under CHS

\section{Age Distribution of the Respondents}

The respondent's age distribution was analyzed, and according to the findings, most respondents, 23, representing $41.07 \%$, showed that they were in the 26-35 age bracket. However, a considerable number of 15 respondents, a percentage of 26.79 and 11 a percentage of 19.64, indicated they were between 36-45 and 4655 , respectively. Respondents within the age bracket of 18-25 were eight, a percentage of 8.96 , and the respondents who were over 55 were only 2 representing a percentage of 3.57 . From these findings, it is evident that most of the respondents working at CHS Nyeri County are within the age bracket that is most productive, and they are advantaged with the M\&E practices knowledge. Therefore, it assisted in determining the effects of M\&E practice on the performance of health projects. Damascene, (2019) supports these findings by highlighting that the respondent's level of education backs the understanding of the different monitoring and evaluation practices and the project performance.

\section{Level of Education of the Respondents}

The respondent's level of education was analyzed, and from results from the study findings, majority of the respondents (29), $51.79 \%$ had a college diploma, while a good number $16(28.57 \%)$ had a college certificate, while (9) $16.07 \%$ had a bachelor's degree. Only $2(3.57 \%)$ of the respondents had a post-graduate degree. The study findings implied that most of the CHS Nyeri County employee had obtained a tertiary level of education, showing that the respondents had the knowledge, skills, and capacity to understand, support, and adopt the M\&E practices in health projects to increase their performance. This observation concurs with that of Gwagoya, (2017) and Wambua, (2019), who stated that since most respondents have vital academic qualification, they can effectively communicate and thus show a fair representation of all levels of education.

\section{Respondents Position in the Organization}

The respondents' position in the organization was analyzed, from the findings, social workers were the majority respondents as demonstrated by (20) $35.71 \%$, health record officers' respondents followed with (18) $32.14 \%$, while clinicians were (16) $28.57 \%$ and finally M\&E officers were $2(3.57 \%)$. The collected data was from the respondents holding various CHS positions. Their different sentiments made the data reliable in identifying how monitoring and evaluation practices affect the performance of health projects under CHS.

\section{Work Experience of the Respondents}

The respondent's work experience was analyzed, and from the results, most of the respondents, $51.79 \%$ (29), indicated that they had worked for CHS Nyeri County for 4-6 years. Other respondents, 33.93\% (19) and $12.5 \%$ (7), indicated that they had worked for CHS Nyeri County for a period of over six years and 2-4 years, respectively. Only one respondent $(1.79 \%)$ stated that they had worked for less than two years.

The study findings indicated that most of the respondents, $85.72 \%$ (48), had been engaged in CHS for more than four years, hence having adequate information on CHS planning for M\&E, capacity building of the $M \& E$ team and maintenance of $M \& E$ data quality which affects the performance of health projects. Idoro (2019), in a similar line of findings, highlights that this shows that majority of the respondents were effective owing to their level of experience. Hence experience in health project have significant influence in the performance of health projects.

\section{Summary of Findings}

The key purpose of this study was to establish the effects of M\&E practices on the performance of health projects under the Centre for Health Solutions in Nyeri County, Kenya. The research was carried out in the Center for Health Solutions, Nyeri County, to examine the relationship between M\&E practices and health project performance. The health project performance under Center for Health Solutions was the dependent variable. At the same time, the $M \& E$ practices, planning for $M \& E$, capacity building of the $M \& E$ team and maintenance of the $M \& E$ data quality were the independent variables. Using M\&E practices effectively on health projects guarantees the success of projects and observable project performance that meets all key stakeholders' project objectives and expectations. Effective use of M\&E practice guarantees that health projects perform by producing desirable results of quality and within the set time and budget.

This study concentrated on the performance of the health projects as the outcome variable. The study on the performance of health projects under CHS Nyeri County was measured grounded on three indicators: project cost-effectiveness, timely project completion, and project acceptance. The various questions in relation to if health projects completed on time are an indicator of project performance. Findings from the questionnaires showed that most of the respondents, $51.8 \%$, a mean of 4.07 , agreed that health projects completed on time are indicators of project performance. The next statement to determine if health Projects delivered within budget are an indicator of project performance, that majority of the respondents, $58.9 \%$ a mean of 4.05 , agreed to the statement that health projects delivered within budget are an indicator of project performance. The final statement to identify if acceptance of project output is an indicator of project performance, the majority $42.9 \%$, a mean of 4.23 , agreed that most of the respondents agreed that acceptance of project output is an indicator of project performance.

The study established a strong positive relationship between the performance of health projects under CHS and planning for M\&E, 
as shown by the coefficient of 0.979 . In addition to this, the study established that there is also a relationship that is positive between the performance of health projects under CHS and capacity building of the M\&E team, which had a coefficient of 0.957 . Finally, the study established a positive relationship between the performance of health projects under CHS and M\&E data quality maintenance which had a coefficient of 0.911 . Furthermore, the positive relationship shows a correlation between all the independent and dependent variables, with planning for $M \& E$ having the greatest value and planning for $M \& E$ having the lowest correlation value.

The study had six hypotheses which were based on the following research questions: planning for $M \& E$ has no significant effect on health projects performance, planning for $M \& E$ has a significant effect on health projects performance, capacity building of the M\&E team has no significant effect on health projects, capacity building of the $M \& E$ team has a significant effect on health projects performance, $M \& E$ data quality maintenance has no significant effect on health projects performance, and M\&E data quality maintenance has a significant effect on health projects performance under Centre for Health Solutions in Nyeri County.

\section{CONCLUSIONS, AND RECOMMENDATIONS}

\section{Conclusions}

This study aimed to identify the effects of M\&E practices and the performance of health projects under the Centre for Health Solutions in Nyeri County. The objectives were to assess the effects of planning for $M \& E$ on health projects performance, as well as to determine the significance of capacity building of the M\&E team on the performance of health projects and finally to examine the effects of $M \& E$ data quality maintenance on the performance of health projects under the Centre for Health Solutions.

The findings of these study were aligned with the theories that anchor this study. The study was anchored by program theory and result evaluation theory. The findings of this study shall go an extensive way in relating the use of these theories in understanding the $M \& E$ practices and the performance of health projects. Program theory enlightens how a project performs using $M \& E$ practices to a set of results that produces the anticipated effects. The effects expected can be either negative or positive. The study utilized realistic evaluation theory that stipulates stakeholders, policymakers, M\&E team ought to know how and why policies, programs, or projects operate in different $\mathrm{M} \& \mathrm{E}$ practices. By doing so, they will be better positioned to make decisions regarding which $M \& E$ practices to use and how to adjust them to different situations to achieve the set objectives and have high performance.

As per the study findings, it can be concluded that all the independent variables, planning for $M \& E$, capacity building of the $M \& E$ team and maintenance of the $M \& E$ data quality, significantly positively affects the performance of health projects under CHS the dependent variable. This established through multiple correlation analysis and regression analysis, which presented a positive relationship between the monitoring and evaluation practices and the performance of health projects under CHS, Nyeri County. Thus, the study concluded that the monitoring and evaluation practices affect the performance of health projects under CHS Nyeri County, Kenya, positively.

Based on the literature reviewed, field results, and the comments made during the field study, the research concludes that, without carrying out planning for $\mathrm{M} \& \mathrm{E}$, it would be very challenging to carry out any meaningful monitoring and evaluation activities. From this study, it's evident that for M\&E to affect the performance of health projects, it is important for planning for $M \& E$ to occur. Activities that are important during planning for M\&E include stakeholders' involvement, budget allocation for $\mathrm{M} \& \mathrm{E}$, resource allocation for $\mathrm{M} \& \mathrm{E}$, scheduling of activities for $M \& E$ and utilization of $M \& E$ results. However, study findings highlight that there is a lack of consistent funding for Monitoring and Evaluation activities. Hence there is a need to increase budget allocation to the $M \& E$ department during planning for $M \& E$ since the $5 \%$ organization budget is not fully allocated to the M\&E department. The under allocation of funds derails the $\mathrm{M} \& \mathrm{E}$ activities even though financial resources significantly influence $M \& E$. Likewise, sufficient resources for $M \& E$ have not been allocated to the concerned department affecting monitoring and evaluation, and this may lead to the probability of a project failing to complete due to the lack of resources. It can be noted that the limited resources for $M \& E$ have a negative impact on health project performance.

Capacity Building, the M\&E team, is as important as planning for $M \& E$ in affecting the performance of health projects under CHS. The study results show that capacity building the M\&E team is key to health projects performance. Thus, the project management team should ensure that the M\&E team are competent and skillful, as well as the number of the $M \& E$ team is sufficient, while the M\&E team have ample experience. Finally, the project management team should frequently organize regular monitoring and evaluation training for both in-field and on-field personnel. Capacity building of the M\&E team is important in both planning for $M \& E$ and the maintenance of $M \& E$ data quality. $M \& E$ team ought to be trained on the way to prepare M\&E plans and other $M \& E$ documents required in the project. The $M \& E$ team should also be well trained on ways to collect $M \& E$ data using appropriate M\&E data collection tools and from good M\&E data sources.

$M \& E$ data quality maintenance inconclusive have a positive effect on the performance of health projects under CHS. Data Quality is an important attribute in $\mathrm{M} \& \mathrm{E}$ since most of the collected data are used for decision making and programing in various facets of health projects. Monitoring and Evaluation data is significant and a mandatory component in decision-making processes. Having high-quality data supports the construction of quality decisions in health projects. Therefore, $M \& E$ data quality is one of the important variables to be relied on. In this case, data collection tools and methods, source of M\&E Data, frequency of data collection and usage of M\&E technology are important factors towards the attainment of high $\mathrm{M} \& \mathrm{E}$ data quality. However, according to the field reports, most respondents were not sure or lacked the know-how if employees are regularly trained on effective monitoring data collection tools and methods. Having regularly trained $\mathrm{M} \& \mathrm{E}$ trained on effective monitoring and evaluation data collection tools and methods reduces the chances of collecting information from wrong sources or collecting information not accurate that would fail to reflect the project performance and compromising decision making. 


\section{Recommendations for Practice}

i. According to the field findings, it is recommended to have resources for $M \& E$ that are adequate and timely since they have a significant effect on the performance of health projects. The provision of limited $M \& E$ resources may lead to $M \& E$ activities suffering a setback hence directly affecting the performance of health projects.

ii. The study established that the health projects faced challenge of inadequate finances for $\mathrm{M} \& \mathrm{E}$ activities, and so it recommends allocation of $5 \%$ to $10 \%$ of the organization budget is to the M\&E department. Without an adequate M\&E budget, organizations may be forced to drop some M\&E activates they are mandated to carry out.

iii. The study recommends that non-Governmental Organizations should frequently organize regular training on Monitoring and Evaluation. This would support increasing the knowledge in M\&E. Regular training on $M \& E$ increases the quality of the personnel involved in $\mathrm{M} \& \mathrm{E}$ and hence leads to health project success and high health project performance. Regular training should be emphasized for all personnel and, more precisely, those involved in monitoring and evaluation.

iv. It is important for an organization to regularly train the M\&E team on effective monitoring and evaluation data collection tools and methods. This ensures that those that collect the M\&E data have a clear understanding of what is required of them and what they are doing. Having untrained M\&E personnel leads to the collection of wrong information and collection of information from wrong sources compromising the quality of data hence affecting the judgment during decision making. Regularly training on effectiveness in $\mathrm{M} \& \mathrm{E}$ is highly significant to removing serious compromises that may result from ineffectiveness. In this way, the relationship between $\mathrm{M} \& \mathrm{E}$ and health project performance would be improved.

\section{Recommendations for Further Research in this Field of}

\section{Study}

1. The study sought to establish the effects of M\&E practices on the performance of health projects under CHS in Nyeri County, Kenya.

2. Similar studies can be done in other NGOs in different counties, and the findings to be compared to improve the performance of health projects under NGOs.

3. The study was limited to one NGO; future studies can then use a larger sample to boost the generalization of results.

4. Future studies can be carried out in other sectors and industries to investigate whether similar M\&E practices may have comparable effects on the performance of projects.

\section{REFERENCES}

1) Abraham, B. K. (2018). Influence of project monitoring and evaluation on the performance of youth funded projects: A case of Moiben Subcounty Uasin Gishu County, Kenya . Retrieved from http://41.204.161.209/handle/11295/104158

2) Akello, E., \& Moronge, M. (2019). Influence of monitoring and evaluation on completion of government funded agricultural projects in arid and semi -arid areas of Kenya: A case of Marsabit County. The Strategic Journal of Business \& Change Management, 6(2), 1329 1344.

3) Alex, A. J. (2016, August). Assessment of Performance of Monitoring and Evaluation Systems at Caritas Torit, In South Sudan. Nairobi.

4) Anderson, A. A. (2004). theory of change as a tool for strategic planning: A Report on Early Experiences. The Aspen Institute Roundtable on Community Change.

5) Anunda, J. S. (2016). Factors Influencing The Performance Of Projects Implemented By Ngos In The Health Sector: A Case Of Hiv/Aids Projects In NairobI.

6) Armenia. (2012, March). Armenia Post-Compact Monitoring and Evaluation Plan.

7) Babbie, E. R. (2001). The Practice of Social Research. Cape Town:: Oxford University Press South Africa.

8) Barasa, R. M. (2014). Influence of Monitoring and Evaluation Tools on Project Completion in Kenya. A Case of Constituency Development Fund Projects in Kakamega County, Kenya. Nairobi.

9) Bell, P. (2012). Building a Monitoring and Evaluation System for Climate Change Adaptation Projects: Projects:Challenges and Strategies Towards Stakeholders Involvement. Asian Cities Climate Change Resilience Network (ACCCRN).

10) Bennett, S., Singh, S., S.Ozawa, Tran, N., \& Kang, J. (2018). Sustainability of donor programs: evaluating and informing the transition of a large HIV prevention program in India to local ownership. Global Health.

11) Benson Malombe Mavuti, T. M. (2019). Effect Of Project Management Practices On Implementation Of Kenya Ports Authority.

12) Better Evaluation. (n.d.). BetterEval:World. Retrieved from Better Evaluation: https://www.betterevaluation.org/en/node/5280

13) Bhat, A. (2019). Blog. Retrieved from QuestionPro.com: https://www.questionpro.com/blog/research-design/

14) Bickman, L. (1987). The Functions of Program Theory. San Fransisco : New Directions for Program Evaluation.

15) Centre for Health Solutions. (2020). Centre for Health Solutions-Kenya $(\mathrm{CHS})$. Retrieved from Centre for Health Solutions-Kenya (CHS): https://www.chskenya.org/

16) chskenya. (2020). Centre for Health Solutions-Kenya (CHS). Retrieved from chskenya: https://www.chskenya.org/wpcontent/uploads/2019/11/FINAL-Nyeri-County-Profile-2019_new.pdf

17) CLEAR. (2012). African Monitoring and Evaluation Systems Workshop Report. Johannesburg: University of Witwatersrand. Retrieved from https://www.theclearinitiative.org/sites/clearinitiative/files/201604/african_M\%26E_workshop.pdf

18) Cronbach, L. J. (1951). Coefficient Alpha and The Internal Structure of Tests. Psychometrika.

19) Damascene, J. (2019). The contribution of Monitoring Practices on NGOs Performance in Humanitarian Emergency Responses, a case study of Save the Children Mahama Camp Rwanda 2015-2019.

20) Defontaine, C. (2018, May 8). Exploiting the full potential of new technologies for data collection, monitoring, and conflict prevention. Development for Peace.

21) Dibo, M. (2019). Retrieved from Amref Health Africa. 
22) Dobi, B. A. (2019). Factors Influencing Adoption Of Monitoring And Evaluation System For Project Management Among Ngos In Rarieda District, Siaya County, Kenya. Nairobi, Kenya.

23) Dr.I.Selvaraj. (n.d.). Super 7. Retrieved from Pitt.edu: http://www.pitt.edu/ super7/29011-30001/29361-29371.ppt

24) Edge, J. S., \& Hoffman, S. J. (2016, November 13). Empirical impact evaluation of the WHO Global Code of Practice on the International Recruitment of Monitoring and Evaluation Personel in Australia, Canada, UK and USA.

25) Gebremedhin, B., Getachew, A., \& Amha, R. (2018). Results-based monitoring and evaluation for organizations working in agricultural development: A guide for practitioners. ILRI (International Livestock Research Institute).

26) GoK. (2010). The Constitution of Kenya. Retrieved from Kenyalaw.org: http://www.kenyalaw.org/lex//actview.xql?actid=Const2010\#KE/CO N/Const2010/chap_4

27) Government of Zimbabwe. (2015, May). NATIONAL MONITORING AND EVALUATION POLICY. Harare, Zimbabwe.

28) Guzmán, M., Irarrázaval, I., \& Ríos, B. d. (2020, July). Monitoring and evaluation system: The Case of Chile 1990-2020.

29) Gwagoya, R. A. (2017). Factors influencing effective implementation of monitoring and evaluation practices in donor funded projects in kenya. A case of turkana district. Nairobi.

30) Gyorkos, T. W. (2013). Monitoring and evaluation of large scale helminth control programmes. Acta tropica report, 86(2), 275-282.

31) Hubert, N., \& Mulyungi, D. (2018). Influence Of Monitoring And Evaluation Planning On Project Performance In Rwanda: A Case Of Selected Non Governmental Organisations In Gasabo District. European Journal of Business and Strategic Management, 3(8), 1-16.

32) Hunter, J. (2009). Retrieved from nid.org: https://www.nid.org.na/images/pdf/ngo_management_training/Monito ring_and_Evaluation.pdf

33) Idoro, G. (2019). Influence of the monitoring and evaluation practices of indigenous and expatriate Nigerian contractors on project outcome. Journal of Construction in Developing Countries.

34) IFAD. (2016). Local Initiative Support Project Evaluation Report. Rome: Office of the Evaluation Studies.

35) Ika, L. A., Diallo, A., \& Thuillier, D. (2018). Project Management in the international development industry: the project coordinator's perspective. International Journal of Managing Projects in Business, $3(1), 61-93$.

36) INTRAC. (2001). Practical Guidelines for the Monitoring and Evaluation of Capacity Buidling Experiences from Africa. United Kingdom: INTRAC.

37) INTRAC. (2017). $M \& E$ Training \& Consultancy. Retrieved from Intrac: content/uploads/2017/01/Realist-evaluation.pdf https://www.intrac.org/wpcms/wp-

38) INTRAC. (2015). Practical Guidelines for the Monitoring and Evaluation of Capacity Buidling Experiences from Africa. United Kingdom: INTRAC.

39) Izurieta, A., Sithole, B., Stacey, N., Hunter-Xenie, H., Campbell, B., Donohoe, P., \& Wilson, J. B. (2019, September). Developing Indicators for Monitoring and Evaluating Joint Management Effectiveness in Protected Areas in the Northern Territory, Australia.

40) Japeth, M. N., \& Luketero, D. S. (2017). Influence of Monitoring and Evaluation Practices in Non Governmental Organisation: A case of Maternal Health Projects in Bungoma South Sub-County, Kenya. $\begin{array}{llll}\text { European Scientific } & \text { Journal, }\end{array}$ doi:10.19044/esj.2017.v13n23p11

41) Jennifer, C. (2015). Investing in Monitoring, Evaluation and Learning Issues for NGOs to consider.

42) Kaberia, E. S. (2019). Influence Of Monitoring And Evaluation Practices On Performance Of Projects Funded By Faith Based Organisations In Meru North, Meru County Kenya. Nairobi.

43) Kabonga, I. (2018). Principles and Practice of Monitoring and Evaluation:A Paraphernalia for Effective Development. Africanus: Journal of Development Studies, 48(2). doi:https://doi.org/10.25159/0304-615X/3086

44) Kaburu, R. W. (2015). Factors Influencing Performance of Monitoring and Evaluation Systems in Non-Governmental Organizations:Case of Ngos in Nairobi County.

45) Kamau, P. (2017). Factors Influencing Performance of Monitoring and Evaluation Systems in Non-Governmental Organization Projects: A Case of Aga Khan Foundation in Nairobi, Kenya . Nairobi.

46) Kareithi, R. N., \& Lund, C. (2012). Review of NGO performance research published in academic journals between 1996 and 2008. South African Journal of Science, 108(11-12). doi: http://dx.doi.org/10.4102/sajs.v108i11/12.755

47) Kenya National Bureau of Statistics. (2019). Retrieved from Kenya National Bureau of Statistics: https://www.knbs.or.ke/?wpdmpro=2019-kenya-population-andhousing-census-volume-i-population-by-county-and-sub-county

48) Khan, K. (2018). Strengthening of Monitoring and Evaluation System. Islamabad: Pakistan Poverty Alleviation Fund.

49) Kihuha, P. (2012). Monitoring and Evaluation Practices and Performance of Global Environment Facility Projects in Kenya, A Case of United Nations Environment Programme.

50) Kirori, G. M., \& Karanja, D. N. (2019). Monitoring And Evaluation Practices And Performance of Youth Projects In Non-Governmental Organizations In Kenya. International Journal of Novel Research in Humanity and Social Sciences, 6(2), 89-95.

51) Kissi, E., Agyekum, K., Baiden, B. K., Tannor, R. A., Asamoah, G. E., \& Andam, E. T. (2019). Impact of project monitoring and evaluation practices on construction project success criteria in Ghana.

52) Kiura, H. M. (2017). Influence of Monitoring and Evaluation Strategies on the Implementation of Ng-cdf Projects: a Case of Ngariama Njukiini Water Project Gichugu Constituency Kirinyaga County . Nairobi.

53) Kothari, C. (2004). Research Methodology: Methods and Techniques (2nd Edition ed.). New Delhi: New Age International (P) Ltd.

54) KPMG. (2014). Monitoring and Evaluation in the Development Sector. KPMG International report .

55) KPMG. (2019). Monitoring and Evaluation in the Development Sector. KPMG International report.

56) Kusek, J. Z., \& Rist, R. C. (2004). Ten Steps to a Results-Based Monitoring and Evaluation System : A Handbook for Development Practitioners. Washington, DC: The World Bank.

57) Lahey, R. (2009, November ). Monitoring and Evaluation in the Government of Canada 'Lessons Learned' from 30 Years of M\&E Development.

58) Lammer, \& Badia. (2018, August). Research Methodology. Retrieved from Uca.Edu: https://uca.edu/psychology/files/2013/08/Ch7Sampling-Techniques.pdf

59) Lavrakas, P. J. (2008). Construct Validity. Sage Publications. 
60) Lewis, P., Thornhill, A., \& Sanders, M. (2016). Research methods for business students (4th ed.). Prentice Hall.

61) Maalim, M. A. (2017). Influence of monitoring and evaluation practices on project performance in counties: the case of Mombasa county, Kenya.

62) Mackay, K. (2007). Retrieved from Worldbank.org: http://documents.worldbank.org/curated/en/689011468763508573/pdf /405460REPLACEM18082137191601PUBLIC1.pdf

63) Magondu, A. (2016). Factors Influencing Implementation Of Monitoring And Evaluation In Hiv Research Projects: A Case Of Kenya Aids Vaccine Initiative (Kavi).

64) Maina, W. M. (2016). Influence of monitoring and evaluation factors on performance of co-operative societies in Kenya. A case of Nairobi County.

65) Maphunye, M. (2018). Human capacity challenges in the implementation of a Monitoring and Evaluation. University of the Witwatersrand Graduate School of Public \& Development Management.

66) Marchal, B., Belle, S. V., \& Westhorp, G. (2015). Approaches. (G. Peersman, Editor) Retrieved from Better Evaluation.

67) Marsden, P., Caffrey, M., \& McCaffery, j. (2017). Human resources management assessment approach

68) Mathis, R., \& Jackson, J. (2015). Human resource management. Boston MA: Cengage Learning.

69) Mavuti, B. M., Kisung'u, T. M., \& Oyoo, J. J. (2019). Effect of project management practices on implementation of Kenya Ports Authority.

70) Measure Evaluation. (2007, December). Measure Evaluation. Retrieved from Measure Evaluation: https://www.measureevaluation.org/our-work/data-quality

71) Mensah, S. (2017). the effect of project management practices on bulding project performance: the case of three organizations. retrieved from

https://www.academia.edu/2168131/The_effect_of_project_managem ent_practices_on_building_project_performance_the_case_of_three_o rganizations

72) Mibey, H. K. (2016). Factors affecting Implementation of Monitoring and Evaluation Programs in Kazi kwa Vijana Project by government ministries in Kakamega Central District, Kenya (Unpublished master"es thesis).

73) Ministry of Health. (2019). National Tuberculosis, Leprosy and Lung Disease Program January- Junet 2019.

74) Ministry of Health. (2019). Nyeri County Health at a Glance.

75) Ministry of Health. (n.d.). National Tuberculosis, Leprosy and Lung Disease Program January- June 2020.

76) MoH. (2014). Kenya Health Policy 2014-2030: Towards Attaining the Highest Standard of Health.

77) Msila, V., \& Setlhako, A. (2013). Evaluation of Programs: Reading Carol H. Weiss. Universal Journal of Educational Research, 1(4), 323327.

78) Mthethwa, R., \& Jili, N. (2016). Challenges in implementing monitoring and evaluation (M\&E): the case of the Mfolozi Municipality. African Journal of Public Affairs, 9(4), 102-113.

79) Muchelule, Y. W. (2018). Influence of Monitoring Practices on Projects Performance of Kenya State Corporations. 1-196.

80) Mugenda, O. M., \& Mugenda, A. G. (2003). Research methods. Quantitative and qualitative approaches. Nairobi: Acts Press.
81) Mugo, I. (2018, December 11). Retrieved from Daily Nation: https://www.nation.co.ke/kenya/healthy-nation/nyeri-s-chronicdisease-burden-117472

82) Mugo, N. J. (2017). Monitoring And Evaluation Practices, Ethics And Sustainability Of Agricultural Food Crop Projects In Nyeri County, Kenya.

83) Muiga, M. J. (2015). Factors Influencing the Use of Monitoring and Evaluation Systems of Public Projects in Nakuru County. Univesity of Nairobi.

84) Muindi, J. M. (2018). Influence of Monitoring and Evaluation on Performance of County Funded Social Development Projects in Makueni County, Kenya. Nairobi

85) Mulandi, N. M. (2013). Factors Influencing Performance of Monitoring and Evaluation Systems of Non-Governmental Organizations in Governance: A Case of Nairobi, Kenya.

86) Muniu, F. N. (2017). Monitoring and evaluation practices, community participation and sustainability of Community Water Projects in Kenya: a case of Nyeri county.

87) Mushori, J. (2015). Determinants of effective monitoring and evaluation of county government funded infrastructural development projects, Nakuru East Constituency, Nakuru County Kenya. University of Nairobi.

88) Mutuma, I. K. (2018). Influence Of Monitoring And Evaluation Practices On Implementation Of Core Banking System Project At The National Bank Of Kenya, Nairobi County.

89) Mwangi, S. W., \& Moronge, M. (2019). Influence of monitoring and evaluation practices on performance of world bank funded.

90) Mwendia, A. W. (2017). Dietary Practices and Nutrition Status of Adult Pulmonary Tuberculosis Patients Attending Nyeri County Referral Hospital, Kenya.

91) Nasambu, J. (2016, August). Factors Influencing The Performance Of Monitoring and Evaluation Systems in Non-Government Organizations in Lira District, Northern Uganda. Uganda Technology and Management University (UTAMU).

92) ncert-solution. (n.d.). Retrieved May 16, 2019, from StudyAdda.com: https://www.studyadda.com/ncert-solution/9th-social-sciencepopulation/306/27336

93) NDPC. (2006). Growth And Poverty Reduction Strategy (Gprs Ii)National Monitoring And Evaluation Plan (2006 - 2009) . Retrieved from https://new-ndpcstatic1.s3.amazonaws.com/CACHES/PUBLICATIONS/2016/04/16/G PRS+II+MandE+Plan.pdf

94) Ndung'u, B. (2018). Factors Influencing Implementation Of Monitoring And Evaluation Practices In County Government Construction Projects In Kenya: A Case Of Nyeri County. Nairobi.

95) Nduta, N. N. (2018). Monitoring and Evaluation Strategies, Management Support and Performance of Dairy Primary Cooperative Societies in Murang'a County, Kenya.

96) NGOs Co-Ordination Board. (2019). ANNUAL NGO SECTOR REPORT 2018/19. Retrieved from https://ngobureau.go.ke/wpcontent/uploads/2020/02/ANNUAL-NGO-SECTOR-REPORT-20182019.pdf

97) Ngumbau, V. M. (2015). Role Of Data Quality Assessment In Performance Of Hiv Prevention Projects In National Aids And Sti Control Programme,Nyeri County, Kenya. Nairobi.

98) Njenga, A. G. (2018). Influence of Monitoring and Evaluation Practices in Non Governmental Organisation: A case of Maternal Health Projects in Bungoma South Sub-County, Kenya. European Scientific Journal, 13(23). doi:10.19044/esj.2017.v13n23p1 
99) Njeri, J. W., \& Omwenga, J. Q. (2019, April 3). Influence of Monitoring and Evaluation Practices on Sustainable Projects - A Case Study of The National Aids Control Council. Strategic Journals, 6(2), 132 - 152.

100) Njeri, N. H. (2018). PROJECT MANAGEMENT PRACTICES AND IMPLEMENTATION OF HEALTH PROJECTS IN PUBLIC HOSPITALS IN NYERI COUNTY, KENYA.

101) Njuguna, P. K. (2016). Factors Influencing the Performance of Monitoring And Evaluation Systems in Non-Governmental Organisations Funded Educational Projects in Murang'A County, Kenya. Nairobi, Kenya.

102) Nuguti, E. O. (2009). Project Monitoring And Evaluation; Introduction And The Logical Framework Approach. Nairobi: Ekon Publishers.

103) Nyakundi, A. A. (2014). Factors influencing implementation of monitoring and evaluation processes on donor funded projects. Retrieved from erepository.uonbi.

104) Nyeri County. (2015). NYERI COUNTY HIV \& AIDS Strate gic Plan (2015/2016- 2018/2019)

105) Nyeri County. (2019). County Government of Nyeri. Retrieved from County Government of Nyeri: http://www.nyeri.go.ke/about-nyeri/

106) O’Flynn, M. (2015). Theory of Change. INTRAC.

107) Obunga, R. O. (2017, December). An Assessment of Monitoring and Evaluation Systems of Plan Kenya: a Case Study of Young Health Programme and Adolescent Girls Initiative Kenya, Nairobi. Nairobi.

108) Ochieng, F. O., Chepkuto, P. P., Tubey, D. R., \& Kuto, L. Y. (2017) Effectiveness of monitoring and evaluation of CDF projects in Kenya. A case of. International Journal of Arts and Commerce, 1(6), 1-9.

109) Ofer, Z. (2008). Top management involvement in project management: Exclusive support practices for different project scenarios.

110) Ongondo, J. T. (2017). Impact Of Monitoring And Evaluation On Performance Of Pandipieri Community Development Projects, Kisumu District, Kenya.

111) Ottaviani, M., \& Sorensen, P. (2012). Herd Behavior and Investment : Comment. THE AMERICAN ECONOMIC REVIEW, 90(3), 695-703.

112) Patric, R., \& Kingsley, J. (2019). Health promotion and sustainability programmes in Australia: barriers and enablers to monitoring and evaluation. Global health promotion.

113) Pawson, R., \& Tilley, N. (2004). Retrieved from Semantic Scholar: https://pdfs.semanticscholar.org/011c/82d379c6525e8402bd0bd39a78 0b94297a78.pdf

114) PMI. (2013). A Guide to the Project Management Body of Knowledge $(P M B O K)$ (Fifth ed.). Newtown Square, Pennslyvania: Project Management Institute, Inc.

115) Princeton University. (2016, April 8). Africa Infrastructure. Retrieved from Centre for Public Impact: https://www.centreforpublicimpact.org/case-study/performancemonitoring-in-south-africa/

116) Ramothamo, S. (2015). Monitoring and evaluation of HIV/AIDS donor funded projects in Maseru: An analysis of six organizations. Stellenbosch University.

117) Rogers, P. (2013, March). Better Evaluation. Retrieved from Better Evaluation:

https://www.betterevaluation.org/en/rainbow_framework/define/devel op_programme_theory

118) Samburu County Government. (2017). Samburu County Government. Retrieved from samburu.go.ke: https://www.samburu.go.ke/me/
119) Sanganyi, M. (2016). Implementation Of Monitoring And Evaluation In Infrastructure Projects In Public Secondary Schools In Mombasa County, Kenya.

120) Seith, S., \& Philippines, I. (2012). Evaluation and Theory of Change. Presented at a Workshop on randomized evaluation to improve financial capability innovation for poverty action . (ipa).

121) Sekaran, U., \& Bougie, R. (2009). Research methods for business: a skill-building approach (5th ed.). Haddington: John Wiley \& Sons.

122) Shapiro, J. (2011). Retrieved from Civicus: https://civicus.org/view/media/Monitoring\%20and\%20Evaluation.pdf

123) Shield, P., \& Rangarjan, N. (2013). A Playbook for Research Methods: Integrating Conceptual Frameworks and Project Management. (1 ed.). Stillwater, Oklahoma: New Forums Press.

124) Shihemi, R. (2016). Influence of monitoring and evaluation tools on projects performance of building and construction projects in Kenyan public universities: A case of the University of Nairobi.

125) Statistics, L. (2018). SPSS Statistics. Retrieved from Lund Research Ltd: https://statistics.laerd.com/spss-tutorials/cronbachs-alpha-usingspss-statistics.php

126) Stephanie. (2014, December 12). Statistics How To. Retrieved from Statistics How To: https://www.statisticshowto.com/interveningvariable/

127) Stephen, M. (2015). Monitoring and Evaluation Practices of Ngos Implementing HIV/AIDS Projects in Luwero and Nakaseke. Makerere University.

128) sump-challenge. (n.d.). Retrieved from sump-challenge: http://www.sump-challenges.eu/content/monitoring-and-evaluation

129) Taherdoost, H. (2016). Sampling Methods in Research Methodology;How to Choose a Sampling Technique for Research International Journal of Academic Research in Management (IJARM), $5(2), 18-27$

130) Toscano, S. (2019). Exploring the History and Challenges ofMonitoring and Evaluation in International Nongovernmental Organizations: Complemented by Intern Experience at Save the Children USA.

131) Trochim, W. M. (2000). The Research Methods Knowledge Base (2nd ed.). Cincinnati, OH.: Atomic Dog Publishing.

132) Umugwaneza, A., \& Kule, J. W. (2016). Role of monitoring and evaluation on project sustainability in Rwanda. A case study of electricity access scale-up and sector-wide approach development project (EASSDP). European Journal of Business and Social Sciences, 5(7), 159-177. Retrieved from http://www.ejbss.com/recent.aspx-/

133) UNDP. (2016). Retrieved from web.undp.org: http://web.undp.org/evaluation/handbook/documents/english/pmehandbook.pdf

134) Velasco, M. (2018). Key Principles of Data Quality. Legal Empowernmet Network.

135) Vijida, P. (2020, June 14). The Star. Retrieved from The Star.

136) Vision 2030. (n.d.). Retrieved May 16, 2019, from Epromis.treasury.go.ke: http://epromis.treasury.go.ke/portal/development-strategy/vision2030/pillars/

137) Waithera, S. L., \& Wanyoike, D. (2015). Influence of project bbmonitoring and evaluation on performance ofyouth funded agribusiness projects in Bahati Sub-County, Nakuru. Jomo Kenyatta University of Agriculture \& Technology, Kenya. 
138) Wambua, C. M. (2019). Monitoring and Evaluation Practices and Perfomance of County Funded Education Projects in Makueni County, Kenya.

139) Wanja, P. (2017). Factors Influencing the Performance of Projects in Ngos Funded by Wfp in Kenya: a Case of Action Against Hunger. Nairobi. Retrieved from erepository.uonbi.ac.ke.

140) Westhorp, G. (2019, September). Realistic Impact Evaluation. An Introduction. A Methods Lab Publication, ODI.

141) WHO. (2009, November). health info. Retrieved from WHO.INT: https://www.who.int/healthinfo/HSS_MandE_framework_Nov_2009. pdf

142) Who.int. (n.d.). Retrieved May 16, 2019, from Who.int: https://www.who.int/hdp/e

143) World Bank. (2012). Monitoring and Evaluation : Some Tools, Methods, and Approaches. Washington: World Bank. Retrieved from World Bank: http://siteresources.worldbank.org/EXTEVACAPDEV/Resources/458 5672-1251481378590/MandE_tools_methods_approaches.pdf

144) World Bank. (2017). Monitoring and Evaluation : Some Tools, Methods, and Approaches. Washington: World Bank. Retrieved from World Bank: http://siteresources.worldbank.org/EXTEVACAPDEV/Resources/4 585672-

1251481378590/MandE_tools_methods_approaches.pdf

145) Worthington, R. (2016, December 21). Retrieved from Kwantu:

http://www.kwantu.net/blog/2016/12/21/improvingdata-quality-in-your-international-developmentprogramme

\section{AUTHORS}

First Author - James Titus Gachanja Kinyua, MA (Monitoring and Evaluation) Student, Department of Social and Development Studies, School of Social Science, Mount Kenya University, Kenya: email; jamestitus29@gmail.com

Second Author - Dr. Naomi Nduta Njoroge (Ph.D.), Lecturer, Department of Social and Development Studies, School of Social Science, Mount Kenya University, Kenya: email;

Ndutanjoroge600@gmail.com 